\title{
Introvert Students' Perceptions and Preferences of English Language Teaching through Autonomous Learning: A Focus On EFL Context in STAIN Watampone
}

\author{
Mufidatunnisa \\ English Education Program \\ STAIN Watampone \\ Watampone, Indonesia \\ Mufidatunnisa16@gmail.com
}

\begin{abstract}
Autonomous learning is sometimes linked with the language learner's personal characteristic. One of the factor in evaluating students' performance and strategies is examining what character they brought during the learning process and how they participate in the classroom. Unfortunately, many English teachers still skip this part and assume that it does need to understand students' temperament to promote ELT in the class. This study aims at finding out the perceptions and preferences of STAIN Watampone students particularly introvert students who have been taught English through autonomous learning system. Using interviews, it was revealed that the introvert students show more enthusiasm and positive response than extrovert in learning English. The finding shows that the use of autonomous learning system can encourage introvert students to participate in the class and help the teachers to meet their introvert students' expectations easier. It indicates that teachers or the stake holder can optimize discussions and projects to suit introvert learners' preferences of ELT in the future.
\end{abstract}

Keywords-English Language Teaching; Autonomous Learning; Introvert Students

\section{INTRODUCTION}

The way students establish their learning style determine the performance on their learning. To meet the need of the suitable learning style, the teachers sometimes offer and prepare many preferences for what they are going to share in classroom. How the students interact and access information, the materials are easily taught become the consideration in reaching the need for all students in spite that some students still get bored or get detached of what they are gaining in the class. On this matter, the teacher sometimes forgot the fact that no single language learning methodology fits all students since it commonly influenced by the personality of each student. It is overbold to think that a single language learning methodology could be possibly fit an entire class filled with students who have a range of stylistic and strategic preferences.

There is a number of a significant relationship between the learning style and strategies, psychology and the accomplishment of the students that the teachers, the students, and the parent need to understand. Some students are expected to talk fluently in the speaking class, interpret and retell the story that they read in front of the whole class and ended up with exhausting feeling, depressed. It caused by the overthinking of failure, laughter, and ridicule possibly comes from their friends. Literally, it is explained as an introvert and this kind of student gained energy from the solitude so it will be pretty hard to force them to perform in the class that way. Thereto, most of the teacher presumes the reward of class engagement simply by oral contributions which was domain by students who are categorized as extrovert-gain the energy from the external words. Extrovert or literally talkative students commonly related smarter and outstanding. It's urgent to create the environment needed for the invisible adolescence students to flourish. Moreover, to get better result, two hours of meeting in the classroom is not enough with the consideration that the introvert students gave less contribution during the learning activity. The students, especially introverted need a platform to build comprehensive understanding about the language they learn. Therefore, the barriers of English Foreign Language Learners in learning language will be slowly decreased.

Autonomous learning system or style would be the answer. Simply put, autonomous is commonly defined by expert as the independence of taught, individualized decision-making and critical intelligence. Learning styles is the general approaches - for example, global or analytic, auditory or visual - that students use in acquiring a new language or in learning any other subject. Reference [11] said these styles are "the overall patterns that give general direction to learning behavior". Autonomous learning style is expected to help introvert students cope with negative peer 
pressure in the classroom which does not really fit the regular teaching system, styles or strategies. Yet, they demand particular competence which is not available and require more time to deal with. Further, Reference [14] said that it helps learners to assume greater control over their own learning it is important to help them to become aware of and identify the strategies that they already use or could potentially use.

Despite the barrier introvert students' face in the class, there are some studies reported that there is no significant relationship between language proficiency and personality types. Reference [9] said that Introverts need different kinds of instruction from extroverts, but often very little is made available to that learner except constant advice on becoming more outgoing and social. Thus, the aim of this study is to give a further support and guidance in strengthening the idea of personality effect on language learning, particularly for introvert students.

\section{LITERATURE REVIEW}

\section{A. Introvert students' characteristic}

Personality plays an important role in reaching the competence of language learning. It should be noted that personality types is generally an important factor in determining human behavior; and these factors affect the way people respond to stimuli and the way they prefer to learn as in reference [1]. For instance, there are students who talk spontaneously with less reflection and produce inaccurate result while the half one did less talk due to the reluctant feeling of being embarrassed by their peers. Thus, the spontaneous one could ask the teacher easily while another one keeps the answer inside with pressure and discrimination.

Friedman and Schustack described there are two main characters of persons. They are extrovert and introvert. Both of these terms are in contradiction. Reference [5] stated that they affect someone's communication competence because motivation and egoism between extroversion and introversion are different. Extroverts tend to like movement, stimulation and collaborative work. Introverts prefer lectures, downtime, and independent projects. Yet it is oversight to assume that introvert is the same way to shyness. In fact, both of them are different. Introversion is not shyness, shyness is a fear or anxiety about social situations and can feel lonely and isolating. Introversion is a natural trait. Reference [9] said that the shy person is afraid to speak up fearing judgment, while the introvert is simply overstimulated needing to retreat -but to the observer, on the outside the two appear to be the same. Related with that, Carl Jung, known as psychiatrist and psychotherapist who first categorized the introvert and extrovert, proposed and divided the type of introvert into four typological groups: a. introverted sensors, b. introverted intuitors, c. introverted thinkers, d. introverted feelers. Reference [7] is concerned with only the introversion term in common. In accordance with the type of introvert students, Myers Briggs in Brown (2000: 156) classified it as follows:

\begin{tabular}{|l|l|}
\hline NO & TYPE OF INTROVERT PERSON \\
\hline 1. & Territorially \\
2. & Concentration \\
3. & Internal \\
4. & Depth \\
5. & Intensive \\
6. & Limited relationship \\
7. & Conservation of energies \\
8. & Interest in integral reaction \\
\hline
\end{tabular}

\section{B. Autonomous Learning}

The fundamental reason for taking autonomous learning sometimes come from the need of students who do not like to work corporately. There are some confusion people cope about autonomous learning. Many related concepts which are similar to the idea of autonomous learning often alternately defined or assumed in the same way with self-directed learning. Reference [10] Self-directed is a concept widely used in the context of learner autonomy and resumed as an entity. Reference [8] stated that the concept of autonomy, which is frequently associated with the concept of independent learning, self-directed and selfregulated learning has been viewed as a fundamental component of good teaching and learning. Additionally, based on Holec, he described autonomous learning as Reference [14]; 1) the ability to take charge of one's learning. On a general note, the term autonomy has come to be used in at least five ways, 2): a) for situations in which learners study entirely on their own; b) for a set of skills which can be learned and applied in self-directed learning; c) for an inborn capacity which is suppressed by institutional education; d) for the exercise of learners' responsibility for their own learning; for the right of learners to determine the direction of their own learning.

These authors perceive that autonomy requires the teacher roles in adapting with the learning strategies for all students in the class. Reference [6] said that the strategies are filled with planning for learning, monitoring of comprehension or production when strategies are being used, and evaluating by the learners themselves after the learning activity has finished. To some extent, the students have a right and power to design and manage their learning style. It entails that the learner will develop a particular kind of psychological relation to the process on content of the learning. There are three levels of control in learner autonomy reference [2]: 1) Learning management/ learning behavior, 2) Cognitive Process/ Psychology of learning, 3) 
Learning content, language learning/ Autonomy in learning situation.

\section{Students' Perception and Preferences}

\section{a. Goal setting}

Reference [6] Goal-setting in language learning is commonly regarded as a metacognitive strategy encouraging learner autonomy. In promoting self-efficacy, Locke and Latham stated that personal goals are not always relevant in increasing goal commitment and/or increasing performance, although choosing a goal (and telling others) may lead to greater feelings or self-control or commitment and, therefore, to better performance. Additionally, research also found that self-efficacy helps people to understand their own capability and can lead them to reach the higher achievement. Regarding the introverted students, many of them get less confident even efficacy in pursuing their need due to some pressure around them, the different goal their schools have which does not suit them or even from the personality itself. Supporting the idea, reference [6] based on related studies, Bandura stated that goal choice without selfefficacy would not lead to increase performance, which points to the conclusion that it is a vital component of personal goal setting. However, the goal-setting is an urgent part to be put as the element for introvert students' perception.

\section{b. Learning Style and Strategies}

Learning styles are the general approaches - for example, global or analytic, auditory or visual - that students use in acquiring a new language or in learning any other subject. These styles are according to reference [11] "the overall pattern that give general direction to learning behavior". Language learning styles and strategies are among the main factors that help determine how -and how well -the students learn a second or foreign language. Reference [13] There are four dimensions of learning styles that are likely to be among those most strongly associated with language learning: sensory preferences, personality types, desired degree of generality and biological difference. But due to the main focus of this study is introvert, then personality types will be much wider discussed. Introvert means a person who is more concerned with his own emotions and feeling than in issues outside himself. In other words, it means being too shy to join social activities and extrovert is the contradict. School system sometimes does not give a space to the introvert to grow, but when autonomous learning was applied, still, there are big questions for the teacher to answer. Hence, their perceptions are needed. After recognizing the style, the students brought in the class or our out of the class, the learning strategies is the next choice to get better performance in learning. The students typically use learning strategies that reflect their basic learning styles. For instance, to acquire language, the introvert students will do the different way than the extroverts. By understanding their learning style, they will create their learning strategies to accomplish their tasks. Be that as it may, teacher can actively help students "stretch" their learning styles by trying out some strategies that are outside of their primary style preferences. Reference [11] states that There are at least six major groups of language learning strategies have been identified by Oxford.

- Cognitive Strategies enable the learner to manipulate the language material in direct ways, e.g., through reasoning, analysis, note-taking, summarizing, sythesizing, practicing in naturalistic settings, and practicing structures and sounds formally.

- Metacognitive strategies (e.g., identifying one's own learning style preferences and needs, gathering and organizing materials, arranging a study space and a schedule, monitoring mistakes, and evaluating task success, and evaluating the success of any type of learning strategy) are employed for managing the learning process overall.

- Memory-related strategies enable learners to learn and retrieve information in an orderly string (e.g., acronyms), while other technique create learning and retrieval via sounds (e.g., rhyming), images (e.g., a mental picture of the word itself or the meaning of the word), a combination of sounds and images (e.g., the keyword method), body movement (e.g., total physical response), mechanical means (e.g., flashcard), or location (e.g., on a page or blackboard) (see Oxford, 1990 for details and multiple examples).

- Compensatory Strategies (e.g., guessing from the context in listening and reading; using synonyms and "talking around" the missing word to aid speaking and writing; and strictly for speaking, using gestures or pause words) help the learner make up for missing knowledge.

- Affective strategies such as identifying one's mood and anxiety level, talking about feelings, rewarding for good performance, and using deep breathing or positive self-talk.

- Social strategies (e.g., asking questions to get verification, asking for clarification of a confusing point, asking for help in doing a language task, talking with a native-speaking conversation partner, and exploring cultural and social norms) help the learner work with others and understand the target culture as well as the language.

\section{c. Self-assessment/ peer-assessment}

Reference [4] defines self-assessment as a natural element of autonomous learning sine. It gives the learner a sense of consciousness of the immediate feedback on their language proficiency and learning strategies. He continued that self-assessment as a tool that can increase motivation and also set some rules for the teacher in this process like raising awareness among the learners of the benefit of selfassessment, providing guidance how to self-assess and helping learners to understand the result. 


\section{METHODOLOGY}

This study is an attempt to discover the introvert students perception and preferences through autonomous learning system. This study uses qualitative research based on descriptive data and the objective tends to understand rather than to generalize. The student from the third until the seventh semester of English Education Program in STAIN Watampone serve as the subject in this study. The type of instrument in this study using semi-structured interview in the form of an open-ended question that is applied to the twenty students of English Education Program in STAIN Watampone. These twenty students are selected by their personality as introvert which observed by their teacher and the researcher. Simply put, after categorized by using observation they are conducted to answer the psychology test and measured by MBTI (MyersBriggs Type Indicator), Quite Revolution test and interview. Further, the students are required to have an autonomous learning experience. The researcher tried to gain information about student perceptions and preferences for both in the classroom and self-study settings. The interview questions concentrated on five aspects of students perception regarding to autonomous learning in terms of (1) the extent to which the introvert students got a positive influence through goal-setting in autonomous learning; (2)how desirable of the introvert students in developing their learning styles and strategies; (3) The ability to determine the material during the learning process; (4)the impact of self-assessment and the students' attitude toward autonomous learning; (5) the challenge they face during applying autonomous learning style. The interview questions were conducted in Indonesian language to reduce the participants' anxiety and elicit more information. The interviews were analyzed through content analysis. The interviews recorded was transcribed to make it easier in understanding the students' statements. The next is reading the interview transcripts and examined in depth, which may lead to formulating initial categories, themes, and relationships. And the last is making interpretation based on the data presented.

\section{RESULT AND DISCUSSION}

The result shows that the students have positive responses towards the autonomy learning. Setting their goal in the class helps them to recognize their own need, they tend to know what they want to achieve, what to concentrate on and what to improve from their self. From the side of introvert student who faced difficulty confounding in the class, one of them stated that:

"I don't expect the test shows that I am introvert, I just sometimes feeling shy and distracted by the situation in my class. Learning autonomously, make my vision clearer and sharper intention toward my study. I can see and reflect my achievement, what I have done and what I was capable of. I am much more disciplined since I always set the goal accurately, whether it comes to dates or times. In classroom, I was always in confusion, I was always left behind in learning grammar. I had no time to express my flurry due to the students in the class was beyond number. Fortunately, I found one of the online course on Facebook which provides a good time-schedule and gave me the explanation of my advancement. It does not change the way I react in the class anyway, I still love the introvert side in myself, I still love to be calm as the way I am but the difference goes to the understanding I got, even though I still feel reluctant to propose questions in front of my friends but I got a better result on my grammar."

Reference [3] said that it is explained by Rogers that the more the learners can freely and openly explore learning experiences, the greater the chance that they will exhibit their creativity and participate in productive ways in the world at large. It is such a good information for the teacher also since prior to the autonomous learning, introvert students also get a low score in grammar class.

In term of the learning style and strategies, the participants found it's easier for them to cope with. Respondents were asked about the place in which they learned autonomously as well as the device they sometimes utilized for such endeavors. Typically, some detailed their passions; playing game which eventually suits their need. A lot of game based education in Playstore are available to access such as Duolingo, Elevate. These applications are designed for learners to enjoy the learning activity. More interestingly, students can choose the frequency of learning and notification to see the progress. Thus, the students are able to study while playing at the same time, gained more knowledge and uplifted their skills. Other mentioned, as their hobby are cooking and jogging, they sometimes found their learning styles by listening to the podcast and made it as strategies. In addition, one of them stated that he was so busy then it is quite hard to find the time schedule in the noon. Thus, he preferred to improve his listening proficiency while jogging in the early morning. He found that activity delightful for his strategies since he is more concentrated in the morning and tends to be focus. After listening section, he sometimes trained himself to talk out loud in the early morning for about ten to twenty minutes. He tends to prefer auditory and kinesthetic for his learning styles and strategies. It is aimed to build self-confidence and upgrade his speaking skill. "I record my voice and listen it again". From the total amount of interviewee, at least most of students are indicated preferring meta-cognitive strategies to help them study. Memory-related strategies come the second choice for the introvert students, and compensatory became the third one respectively. Reference [11] said that it is strengthening from the literature shows that students typically use learning strategies that reflect their basic learning styles.

Self-assessment gave contribution to the learners' growing consciousness. Since the introvert students love to work alone and intensely on the project they care about, they tend to be shy to be mentioned in front of class. Thus, self- 
assessment such as reflective journal writing is thought really useful for them.

"I use it as personal self-evaluation. I sometimes feel reluctant to speak up and ask my peer related to my progression. But, when it comes to self-assessment, I sometimes feel motivated for my friends' comments or simply be able to notice my mistakes. Moreover, I could make a one-on-one counseling meeting with my teacher. The teacher asked my progress whether I obtain enhancement or not, the concrete example of my English improvement and also related to my personality as an introvert language learner." Feedbacks from the students mostly come with positivity yet it normally cited that there are some troubles and challenges on it. For instance, one of the interviewee claimed that autonomous learning outside of the classroom using online course application devote less self-assessment due to the lack of explanation on their language proficiency and learning strategies. Reference [12] believed that it is relieved that the introvert students could fulfill the characteristic of language learners to be proactive and selfmotivated. Reference [3] assumed the barriers or challenges the students face sometimes from less immediate feedback and guidance, impersonalization, procrastination, and becoming overwhelmed by the resources made available. Furthermore, even though the introvert students love to learn independent but one of respondent stated that they still need discussion group technique to sharpening and broadening their idea.

\section{CONCLUSION}

Considering all of related literature and from other sources, this may have affected that the implementation of autonomous learning for students particularly for introvert students need to be discussed further. The findings revealed that introvert students can experience the new sense of freedom to learn since the education world was assumed created only to cater extrovert students. Those introvert students are now aside of being distracted due to the existence of available application that facilitates them to learn on their own leisure time and convenience. More students also argued that they gain selfefficacy by recognizing their learning strategies and could eventually set their goal based on their needs and preferences. Reference [11] said that it has relation to one of research from Nunan, 1997 that strategy instruction led to increased EFL learning motivation. Additionally, the ability to manage their learning process and the students eventually could make a reflection to the level of their learning proficiency. The teachers should consider the learning approach or strategies in a various way to enhance the introvert students competence since there have so much beneficial results from the students' side. Thus, findings of this study can contribute directly to the teachers, policy makers and it also indicates that teachers or the stake holder can optimize discussions and projects to suit introvert learners' preferences of ELT in the future. Lastly, the researcher hopes to look more research closely at the connection between introvert students to the language learners system particularly autonomous learning.

\section{ACKNOWLEDGMENT}

Mufidatunnisa was born on June, 25th, 1995, in Labessi and grew up in Watampone, South Sulawesi. As her concern for education, she spent her entire life; teaching at Islamic Boarding School Al-Junaidiyah Biru and also have weekly meetings with elementary school students, volunteering at Keluarga Pelajar Wija Tho Bone as her effort to increase human resources especially scholars in Bone, part time instructor in Briton International English School Branch Bone, writing some articles or poems in newspaper or due to her passion is sharing (Harian FAJAR, Hipwee). Eventually, she gained achievement from her passion and persistence. December 2015, she became the representative of STAIN Watampone for Student Mobility Program in Australia held by Ministry of Religious Affairs of the Republic of Indonesia. May 2016, she was selected as a contributor to Habibie The Series; A celebration for 80th of Prof. Dr.-Ing. H. Bacharuddin Jusuf Habibie, published by PT Tiga Serangkai. August 2016, she was invited to present her paper in International Conference (BUAF: Borneo Undergraduate Academic Forum) in Pontianak, West Kalimantan. She was selected as presenter for AICIS in Lampung (2016). Afterwards, she was invited as a guest-speaker for scholarship talk show in UIN Banjarmasin (2016) and became the top eight English debate competition in PIONIR, Aceh (2017).

\section{REFERENCES}

[1] Altunel, Veysel. "The impact of extroversion and introversion on language learning in an input-based EFL setting” 2015.

[2] Bharathi, DR. P. "self-directed learning and learner autonomy in English language teacher education: emerging trends." International journal for teachers of english volume 4, issue 1, issn 2230-9136 (print) 2321-7170 (online), 2014: 5.

[3] Curtis J. Bonk, Mimi Miyoung Lee, Feng-Ru Sheu, Xiaojing Kou. "Rresearch on self-directed infromal learners in open educational enviorenments and massively open online course." A Look at SelfDirected Online Learning, n.d.: 1-24.

[4] Gholami, Hamid. "Self Assessment and Learner Autonomy ." Theory and practice in language studies, Vol. 6, No. 1, pp. 46-51, 2016: 46-51.

[5] Hakim, M. Arif Rahman. "Experience efl teachers' challanges and strategies in teaching speaking for introvert students ."European Journal of Social Science, ISSN 1450-2267 Vol. 48 No 4, 2015: $437-$ 446.

[6] Hobbs, Tomoko Koda-Dallow and Moira. "Personal goal-setting and autonomy in language learning." Supporting Independent English Language Learning in the 21st Century: Proceedings of the Independent Learning Association Conference Inaugural. 2005. 1. 
[7] Lawrence, William K. "The experience of introverted reflective learners in a world of extroverts" UK: Cambridge Scholars Publishing, 2015.

[8] Lengkanawati, Nenden Sri. "Learner autonomy in the indonesian efl setting." 2017: 223.

[9] Leung, Winnie Frances. "Supporting introversion and extroversion learning styles in elementary classrooms." 2015.

[10] Parinaz Mohammadi, Sayed Mahdi Araghi. "The relationship between learners' self-directed learning readiness and their english for specific purposes course accomplishment at distance education in Iran." Studies in Self-Access Learning Journal , 2013: 74

[11] Rebecca L. Oxford, PhD. "Language learning styles and strategies: an overview”. GALA, 2003.

[12] Reinders, Hayo. "Towards a classroom pedagogy for learner autonomy: a framework of independent language learning skills." n.d.: 1-17.

[13] Sadeghi, Nabiollah. "Learning styles, personality types and reading comprehension performance." www.cssenet.org/elt Vol. 5, No. 4, 2012 $117-123$.

[14] Thanasoulas, Dimitrous. "Autonomy and learning: an epistemological approach." Applied Semiotics , 116: 2000. 